\title{
KIPIN PTO SEBAGAI MEDIA ASESMEN DIGITAL PEMBELAJARAN DARING DI TENGAH PANDEMI COVID-19
}

\author{
DERIS SUSIYANTO \\ SD Negeri 011 Titian Resak \\ e-mail: derissusiyanto44@guru.sd.belajar.id
}

\begin{abstract}
ABSTRAK
Masa pandemi covid 19 memberikan pengaruh yang besar bagi kehidupan manusia, sehingga mengubah gaya hidup dan rutinitas manusia. Hal ini juga mengakibatkan perubahan di dunia pendidikan yang semula kegiatan pembelajaran dengan tatap muka berubah menjadi pembelajaran jarak jauh yang sering disebut pembelajaran daring. Untuk mempermudah pembelajaran daring diperlukan media yang membantu pendidik dalam pembelajaran salah satunya menggunakan media aplikasi Kipin PTO. Kipin PTO merupakan program digitalisasi asesmen sekolah yang memungkinkan pelaksanaan evaluasi pembelajaran (latihan soal atau try out, penilaian harian dan ujian di sekolah) secara digital berbasis online tanpa menggunakan kertas lagi. Kipin PTO sangat bermanfaat baik bagi sekolah, guru, siswa dan orang tua. Manfaat bagi sekolah Kipin PTO menyediakan fasilitas asesmen berbasis digital yang mudah dan lengkap, terjadi penghematan biaya fotocopy kerta yang besar tiap bulannya. Manfaat bagi guru diantaranya dapat membantu tugas guru dalam membuat paket soal yang mudah dan cepat, tidak perlu koreksi nilai lagi, dan ada Analisa soal. Manfaat bagi siswa, siswa mendapatkan kesempatan sebanyak-banyaknya untuk latihan soal, akses cukup pakai gadget. Kegiatan asesmen menjadi labih menyenangkan. Dengan keunggulan-keunggulan tersebut dapat meningkatkan daya eksplorasi siswa, serta terjadi peran aktif dan partisipasi siswa dengan sesama temannya secara kompetitif dalam pembelajaran. Sehingga pembelajaran di kelas menjadi lebih aktif dan kreatif, menarik dan tidak membosankan, sehingga akan memotivasi siswa dalam pembelajaran, yang pada akhirnya dapat meningkatkan pemahaman siswa terhadap materi pelajaran. Berdasarkan hasil survei responden peserta didik terhadap pemanfaatan Kipin PTO dalam pelakasanaan asesmen digital mencapai persentase 82,6\%.
\end{abstract}

Kata Kunci: Kipin PTO, Asesmen Digital, Pembelajaran Daring

\section{PENDAHULUAN}

Revolusi industri 4.0 memberikan dampak disegala bidang kehidupan termasuk dalam bidang pembelajaran. Pembelajaran di era revolusi induri 4.0 menuntut guru memiliki keterampilan literasi digital. Literasi digital adalah kemampuan menggunakan teknologi dan informasi dari alat digital secara efektif dan efisien dalam berbagai konteks seperti akademik, karir dan kehidupan sehari-hari (Paul Gilster, 1997).

Asesmen merupakan bagian intergral dan berada di jantung proses pembelajaran. Salah satu inovasi sistem asesmen hasil belajar dalam era revolusi industri 4.0 adalah dengan digital assessment. Ada beberapa alasan mengapa digital assessment penting digunakan untuk melakukan asesmen hasil belajar siswa, antara lain: dapat menghemat waktu, membuat proses pembelajaran lebih komprehensif, ramah, dapat memberikan umpan balik yang cepat, dapat memberi umpan balik secara cepat dan dapat mencegah plagiarism dalam menyelesaikan tugas. Digital assessment terkait dengan penggunaan perangkat lunak (softwere) sebagai alat bantu dalam penilaian interaktif.

Asesmen dan evaluasi pembelajaran dalam kondisi social distancing dan physical distancing dimasa pandemi covid-19 yang dilakukan di rumah dapat menggunakan metode asesmen digital. Dengan pesatnya perkembangan dan kemajuan teknologi saat ini, penerapan asesmen digital sangat dimungkinkan dan dimudahkan, terutama dengan adanya jaringan internet. Guru dapat memanfaatkan media aplikasi atau software yang terhubung dengan jaringan internet untuk melakukan asesmen dan evaluasi hasil belajar secara daring. Asesmen 
tersebut dapat berbentuk kuis, tes daring, penugasan-penugasan individu, ataupun dengan bentuk-bentuk asesmen daring lain dengan pemanfaatan internet.

Asesmen pembelajaran merupakan salah satu aspek penting pada proses pembelajaran. Dengan melakukan asesmen pembelajaran, guru dapat mengetahui seberapa berhasil penyampaian materi yang dilakukan saat kegiatan belajar mengajar. Sesuai dengan pendapat yang disampaikan Edwind \& Gerald W. Brown dalam Supriyadi (2011) bahwa aesemen pembelajaran merupakan proses untuk menentukan nilai dalam pembelajaran.

Pengggunaan teknologi dalam Pendidikan merupakan suatu hal yang penting, demi kelancaran pembelajaran di kelas. Salah satu bagian terpenting dalam pembelajaran adalah penggunaan media pembelajaran. Melalui penggunaan media pembelajaran yang tepat akan memberikan manfaat yang bisa dirasakan oleh siswa dalam proses pembelajaran, seperti: dapat meningkatkan motivasi belajar siswa, membantu dalam proses penyerapan materi ajar bagi siswa, tujuan pembelajaran yang ditargetkan tercapai, metode mengajar lebih variatif dan inovatif, serta dapat merangkul secara langsung siswa secara fundamental dan komprehensif. Banyaknya jumlah muatan pelajaran di sekolah menyebabkan siswa lelah menerima materimateri yang disampaikan oleh guru, terlebih jika materi tersebut bersifat teoritis, monoton, tidak menarik,dan membosankan. Sehingga guru perlu menggunakan media pembelajaran yang dapat menimbulkan minat, motivasi, daya nalar, kreativitas, pengembangan potensi, serta rangsangan kegiatan belajar dalam kelas. Ketika guru menyampaikan materi pelajaran hanya dengan metode ceramah dan tanya jawab tanpa menggunakan media pembelajaran yang tepat dan menarik, maka akan mengakibatkan siswa tidak antusias dan kurang bergairah untuk menerima materi ajar atau mengerjakan tes. Media pembelajaran juga merupakan faktor tercapainya keberhasilan pembelajaran. Menurut Abidin (2014: 174) media pembelajaran adalah alat bantu proses belajar mengajar. Sedangkan menurut Aris Shoimin (2014:41) media merupakan wadah dari pesan yang oleh sumber atau penyalurnya ingin diteruskan kepada sasaran atau penerima pesan.

Menurut Irwan dkk (2019) salah satu media pembelajaran yang menarik, memiliki sifat interaktif yang mengutamakan kerjasama, komunikasi, dan bisa menimbulkan interaksi antar siswa adalah melalui permainan, yang mempunyai karakteristik untuk menciptakan motivasi dalam belajar.

Penguasaan teknologi pembuatan dan pemanfaatan media pembelajaran berbasis teknologi informasi mutlak dalam menghadapai era revolusi 4.0. Hal ini diperlukan agar pembelajaran menjadi dinamis, interaktif, dan intensif. Media pembelajaran dengan Kipin PTO merupakan program digitalisasi asesmen sekolah yang memungkinkan pelaksanaan evaluasi pembelajaran (latihan soal atau try out, penilaian harian dan ujian di sekolah) secara digital berbasis online tanpa menggunakan kertas lagi. Kipin PTO sangat bermanfaat baik bagi sekolah, guru, siswa dan orang tua. Manfaat bagi sekolah Kipin PTO menyediakan fasilitas asesmen berbasis digital yang mudah dan lengkap, terjadi penghematan biaya fotocopy kerta yang besar tiap bulannya. Manfaat bagi guru diantaranya dapat membantu tugas guru dalam membuat paket soal yang mudah dan cepat, tidak perlu koreksi nilai lagi, dan ada Analisa soal. Manfaat bagi siswa, siswa mendapatkan kesempatan sebanyak-banyaknya untuk Latihan soal, akses cukup pakai gadget. Kegiatan asesmen menjadi labih menyenangkan. Manfaat bagi orang tua, karena sekolah mampu memberikan fasilitas asesemen sebanyaknya, maka orangtua tak perlu lagi mengikutkan anaknya ke bimbel di luar sekolah. Selain itu Kipin PTO memiliki banyak keunggulan lain diantaranya mendukung model soal AKM : pilihan ganda, pilihan ganda kompleks, menjodohkan, isian singkat, essay atau uraian, memiliki system acak soal seperti UNBK, guru memiliki kemudahan dalam menjadwalkan ujian dengan setting waktu buka tutup, tersedia ribuan bank soal dari semua jenjang, pengerjaan oleh siswa sangat simple yaitu cukup dengan smartphone, laptop atau tablet.

Dengan keunggulan-keunggulan tersebut dapat meningkatkan daya eksplorasi siswa, serta terjadi peran aktif dan partisipasi siswa dengan sesama temannya secara kompetitif dalam pembelajaran. Sehingga pembelajaran di kelas menjadi lebih aktif dan kreatif, menarik dan 
tidak membosankan, sehingga akan memotivasi siswa dalam pembelajaran, yang pada akhirnya dapat meningkatkan pemahaman siswa terhadap materi pelajaran. Kualitas pembelajaran yang meningkat akan berbanding lurus dengan hasil pembelajaran yang juga akan meningkat. Oleh sebab itu perlu kiranya diberikan pelatihan kepada guru dalam memanfaatkan media pembelajaran Kipin PTO di sekolah.

Kipin School 4.0 memiliki konsep yang mirip dengan model pembelajaran berbasis elektronik (e-learning) karena diperuntukkan kepada peserta didik dan guru sebagai media penunjang pembelajaran sehari-hari yang di desain dalam bentuk mobile app berupa software atau media berupa aplikasi yang tersedia untuk berbagai macam device yang tersambung dengan jaringan internet. Kipin school adalah bentuk penyempurnaan dari Kipin ATM dan Kipin PTO (model atau series kipin yang dahulu) karena hanya perlu mengunduh aplikasi kipin school 4.0 di telepon pintar, tablet atau PC untuk mengakses keseluruhan fitur yang tersedia.

Fitur-fitur yang tersedia di dalam kipin school, diantaranya; menu Buku Kurikulum dan Buku Umum, Menu Video Belajar, menu Ujian Online atau try out, menu Literasi, menu Prasekolah, dan menu Sekolahku. Namun dalam pelaksanaannya di SD Negeri 011 Titian Resak aplikasi ini belum dimaksimalkan.

Berdasarkan observasi yang dilakukan pada sekolah di wilayah kecamatan Seberida, diketahui bahwa hampir semua guru di sekolah yang ada di wilayah tersebut belum ada yang menggunakan media digital dalam memberikan pengetahuan kepada siswa disebabkan karena masih gagap dengan teknologi.

Fenomena guru yang gagap teknologi ini dapat di dimaknai sebagai fenomena disrupsi. Menurut Clayton M. Christensen (dalam Kasali 2017:149) Disruption adalah istilah yang menjelaskan fenomena yang muncul dan berkembangnya aplikasi-aplikasi teknologi informasi dalam kehidupan sehari-hari. Rhenald..Kasali...(2017) dalam bukunya yang berjudul 'Disruption' menjelaskan lebih lanjut bahwa disrupsi adalah perubahan besar di bidang teknologi yang mempengaruhi setiap bidang kehidupan (ekonomi, sosial, budaya, hukum, pendidikan, kesehatan dan pemerintahan) yang memiliki dasar melakukan sebuah inovasi yang akan menggantikan seluruh sistem lama dengan cara orang baru.Namun, guru masih cenderung gagap dalam memanfaatkan pesatnya perkembangan teknologi, padahal pembelajaran konvensional sudah tidak relevan jika diterapkan secara terus menerus dalam proses pembelajaran, karena peran teknologi sudah menjadi kebutuhan utama yang melekat dengan peserta didik.

\section{METODE PENELITIAN}

Metode penelitian yang digunakan dalam artikel ini yaitu metode deskriptif yang mendeskripsikan bagaimana cara memanfaatkan aplikasi Kipin PTO sebagai media asesmen digital selama pembelajaran daring dimasa pandemi covid -19 dan dengan menggunakan metode survei. Survei bertujuan untuk mengumpulkan informasi dengan mengajukan pertanyaan secara sistematis kepada responden sehingga mereka dapat menghasilkan analisis statistik yang akurat mewakili populasi yang diminati. Penelitian ini dilakukan dengan menyebarkan angket kepuasan pemanfaatan Kipin PTO sebagai media asesmen digital kepada peserta melalui Google form, yang dapat diisi dalam waktu tertentu di mana pun peserta didik berada. Data yang ada diolah dan dianalisis secara statistik. Persentase rata-rata persepsi peserta didik digunakan untuk mengetahui tingkat kepuasan peserta berdasarkan Indikator Respon Peserta Didik sebanyak 14 butir pernyataan. Peserta didik diminta memberikan respon yang paling sesuai dengan apa yang dirasakan berupa kenyataan dan harapan. Adapun 14 butir pernyataan tersebut adalah sebagai berikut. 
Tabel 1. Butir indikator pernyataan

\begin{tabular}{|c|c|c|c|}
\hline Nomor & Aplikasi & & Indikator/item pernyataan \\
\hline \multirow[t]{14}{*}{1} & \multirow[t]{14}{*}{ Kipin Pto } & 1. & $\begin{array}{l}\text { Pembelajaran menggunakan Kipin membantu saya } \\
\text { memahami materi pelajaran. }\end{array}$ \\
\hline & & 2. & $\begin{array}{l}\text { Saya tidak mengalami kesulitan ketika mengerjakan soal } \\
\text { menggunakan Kipin PTO }\end{array}$ \\
\hline & & 3. & $\begin{array}{l}\text { Saya lebih termotivasi menjawab soal menggunakan } \\
\text { Kipin PTO }\end{array}$ \\
\hline & & 4. & Saya merasa senang menggunakan Kipin PTO saat ujian \\
\hline & & & $\begin{array}{l}\text { Saya bersungguh-sungguh saat mengerjakan soal } \\
\text { menggunakan Kipin PTO }\end{array}$ \\
\hline & & & $\begin{array}{l}\text { Saya senang menjawab pertanyaan-pertanyaan dengan } \\
\text { menggunakan Kipin PTO karena mudah } \\
\text { menggunakannya }\end{array}$ \\
\hline & & 7. & Kipin PTO membantu saya belajar \\
\hline & & & $\begin{array}{l}\text { Saya selalu tertantang mengerjakan soal menggunakan } \\
\text { Kipin PTO }\end{array}$ \\
\hline & & & $\begin{array}{l}\text { Saya tidak mengalami kesulitan dalam menggunaka } \\
\text { Kipin PTO saat mengerjakan soal }\end{array}$ \\
\hline & & 10. & Aplikasi Kipin PTO mudah digunakan \\
\hline & & & $\begin{array}{l}\text { Penilaian menggunakan Kipin PTO lebih menarik dari } \\
\text { pada menggunakan kertas }\end{array}$ \\
\hline & & & $\begin{array}{l}\text { Kipin PTO merupakan salah satu aplikasi untuk } \\
\text { penilaian secara digital }\end{array}$ \\
\hline & & & $\begin{array}{l}\text { Saya merasa puas mengerjakan soal menggunakan Kipin } \\
\text { PTO }\end{array}$ \\
\hline & & & $\begin{array}{l}\text { Saya tidak merasa bosan saat mengerjakan soal } \\
\text { menggunakan Kipin PTO }\end{array}$ \\
\hline
\end{tabular}

Pada penelitian terhadap tingkat tingkat kepuasaan tersebut menggunakan angket tertutup atau terstruktur yang disusun dengan sangat spesifik dimana disertakan pilihan jawaban bagi responden seperti sangat setuju, setuju, tidak setuju, dan sebagainya. Responden diminta untuk memberikan penilaian akan tingkat kepuasaan dalam menggunakan kipin PTO dengan skala penilaian sebagai berikut:

Tingkat kepuasaan peserta didik

a. Sangat setuju $=5$

b. Setuju $=4$

c. Cukup setuju $=3$

d. Tidak setuju $=2$

e. Sangat tidak setuju $=1$

Jumlah peserta didik yang terlibat sebagai responden berjumlah 23 yaitu seluruh peserta didik kelas 6A yang memanfaatkan Kipin PTO sebagai asesmen digital dalam pembelajaran. Sumber data pada penelitian ini yaitu artikel terdahulu, wawancara dan observasi guru mengajar pada proses pembelajaran di masa pandemi covid-19, 2021.

\section{HASIL DAN PEMBAHASAN}

Hasil belajar adalah hasil yang dicapai dalam bentuk angka-angka atau skor setelah diberikan tes hasil belajar pada setiap akhir pembelajaran. Nilai yang diperoleh siswa, dapat dijadikan tolok ukur bisa dalam melihat penguasaan siswa dalam menerima materi PKn. Sedangkan hasil belajar adalah sejumlah pengalaman yang diperoleh siswa yang meliputi ranah kognitif, afektif, psikomotorik (Dimyati dan Mudjiono, 2015: 4). 
Bahkan, belajar tidak hanya penguasaan terhadap konsep teori mata pelajaran saja, akan tetapi juga penguasaan, kebiasaan, dan persepsi, kesenangan dan minat bakat, kesesuaian sosial, macam-macam keterampilan, cita-cita, suatu keinginan, serta harapan. Hal tersebut didukung dengan pendapat Rusman (2017:130), dimana menyatakan bahwa hasil belajar itu dapat terlihat dari terjadinya perubahan dari persepsi serta perilaku, termasuk juga perbaikan sikap atau akhlak.

\section{Pembahasan}

Pemanfaatan media pembelajaran sangat penting dalam proses belajar mengajar. Karena dengan media pembelajaran materi yang kurang jelas menjadi lebih jelas, Media dapat mewakili apa yang kurang mampu guru ucapkan melalui kata-kata, bahkan keabstrakan materi pelajaran dapat dikonkretkan dengan adanya media pembelajaran. Dengan demikian siswa lebih mudah mencerna materi daripada tanpa bantuan media. Maka dari itu seorang guru dituntut harus kreatif dan inovatif untuk mewujudkan pembelajaran yang menarik dan menyenangkan. Dengan cara memperbanyak variasi strategi pembelajaran, metode pembelajaran dan yang penting dapat memilih media pembelajaran yang sesuai dengan kondisi siswa.

Dengan adanya pandemi covid 19 ini mengharuskan kegiatan belajar mengajar dilakukan secara daring. Agar pembelajaran daring dapat berlangsung maka diperlukan teknologi yang menunjang pembelajaran saat ini, teknologi dijadikan media pembelajaran. Salah satu factor penunjang keberhasilan pembelajaran adalah penggunaan media pembelajaran yang tepat, media yang digunakan sebagai wadah penyampaian pesan pembelajaran kepada siswa. Maka dari itu peran guru sangat penting untuk memilih media pembelajaran yang tepat agar dapat mencapai tujuan pembelajaran yang akan dicapai.

Salah satu perkembangan teknologi yang membantu pembelajaran saat pandemi adalah aplikasi Kipin PTO sebagai media pembelajaran. Kipin School 4.0 berisi ribuan konten pelajaran berupa buku, video, latihan soal dan komik pendidikan yang menarik, tingkat PAUD, SD, SMA, SMA \& SMK. Konten interaktif Kipin School 4.0 berupa buku pelajaran sekolah, video pelajaran, latihan soal, komik literasi hingga ujian online berbasis CBT ( Computer Based Test ). Dengan memanfaatkan 'Sekolah Digital', ada 3 keuntungan besar yang akan didapatkan

1. Sekolah mengikuti perkembangan zaman dan tidak ketinggalan dari sekolah lain.

2. Sekolah menghemat biaya yang besar per bulan karena tidak ada biaya pembelian kertas dan cetak untuk ulangan/ujian

3. Siswa memperoleh akses materi pelajaran yang lengkap dan murah.

Kipin School 4.0 ialah sebuah mobile aplikasi berisi : Materi pelajaran K13 (buku pelajaran sekolah, video pelajaran sekolah, latihan tryout dan komik literasi) untuk jenjang SD, SMP, SMA dan SMK plus Sistem Ujian Online. Kipin School 4.0 ini sangat cocok digunakan untuk semua sekolah di Indonesia. Kenapa?

1. Karena Siswa, Guru dan Sekolah akan sangat diuntungkan.

a. Siswa : akan mendapatkan materi pendidikan lengkap (sesuai dengan Kurikulum 2013) secara murah bahkan gratis.

b. Guru : akan terbantu dan dimudahkan ( seperti : guru dapat menentukan waktu pelaksanaan ujian otomatis, ujian dapat dikerjakan melalui gadget, security lengkap agar siswa tidak curang).

c. Sekolah : akan terbantu dengan fasilitas yang tepat ( seperti : sekolah tidak membutuhkan kertas lagi untuk melaksanakan ulangan harian, ujian dll, kecepatan mengolah hasil nilai \{ lebih akurat hasilnya \}, membiasakan siswa dengan sistem USBN/UNBK.

2. Sekolah akan terbantu dalam hal efisiensi dan hemat dalam pengaturan pemanfaatan jalur internet. Kipin School 4.0 sudah dilengkapi dengan teknologi "Download and Go" dimana kalian para pelajar bisa download ribuan materi pelajaran cukup 1x saja (butuh jalur internet) 
dan setelah itu dapat digunakan setiap saat, dimana saja tanpa membutuhkan jalur internet lagi.

a. Sekolah, HANYA BUTUH jalur internet dan device (handphone, laptop, pc)

b. Siswa , TIDAK PERLU membawa banyak buku melainkan cukup membawa tablet, setelah itu siswa dan guru sudah bisa langsung menggunakan Kipin School 4.0

\section{A. Panduan Instal dan Membuat Akun Aplikasi Kipin PTO}

Panduan Instal Aplikasi Kipin di Android

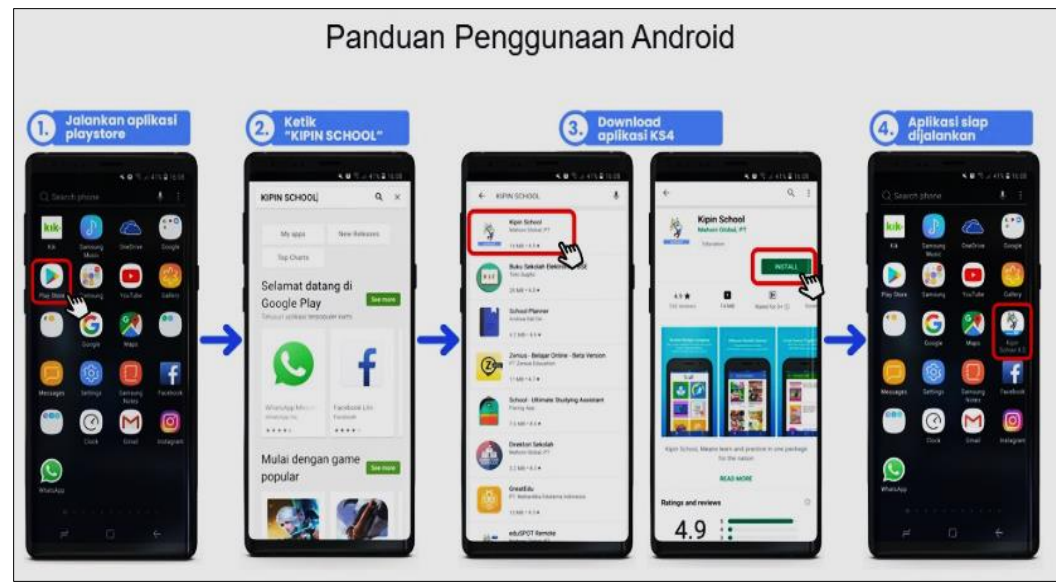

Panduan Instal Aplikasi Kipin di IOS

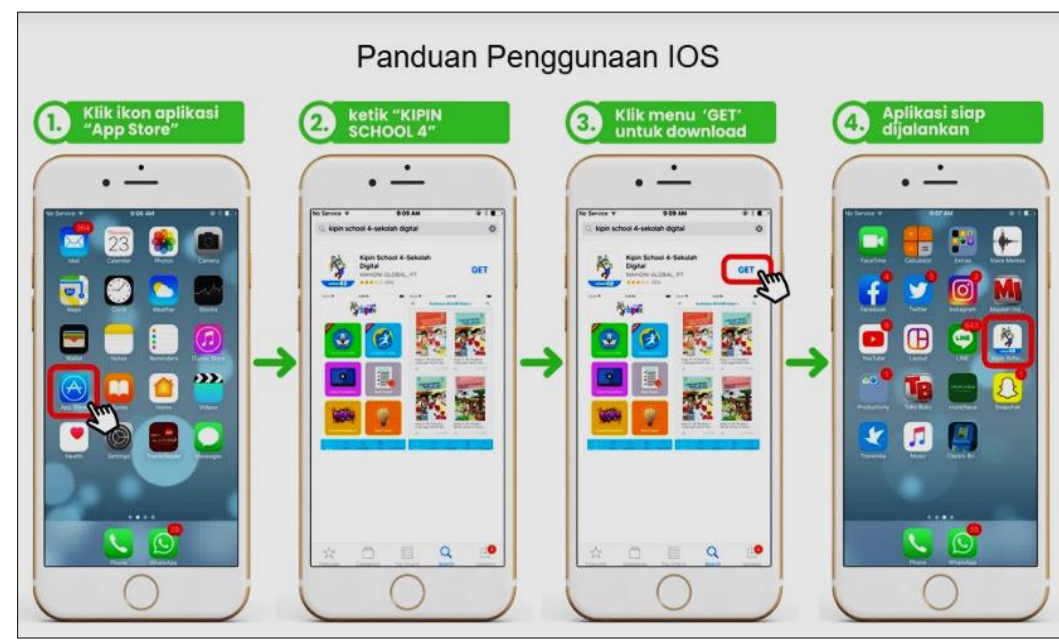

Panduan Instal Aplikasi Kipin di Windows Store

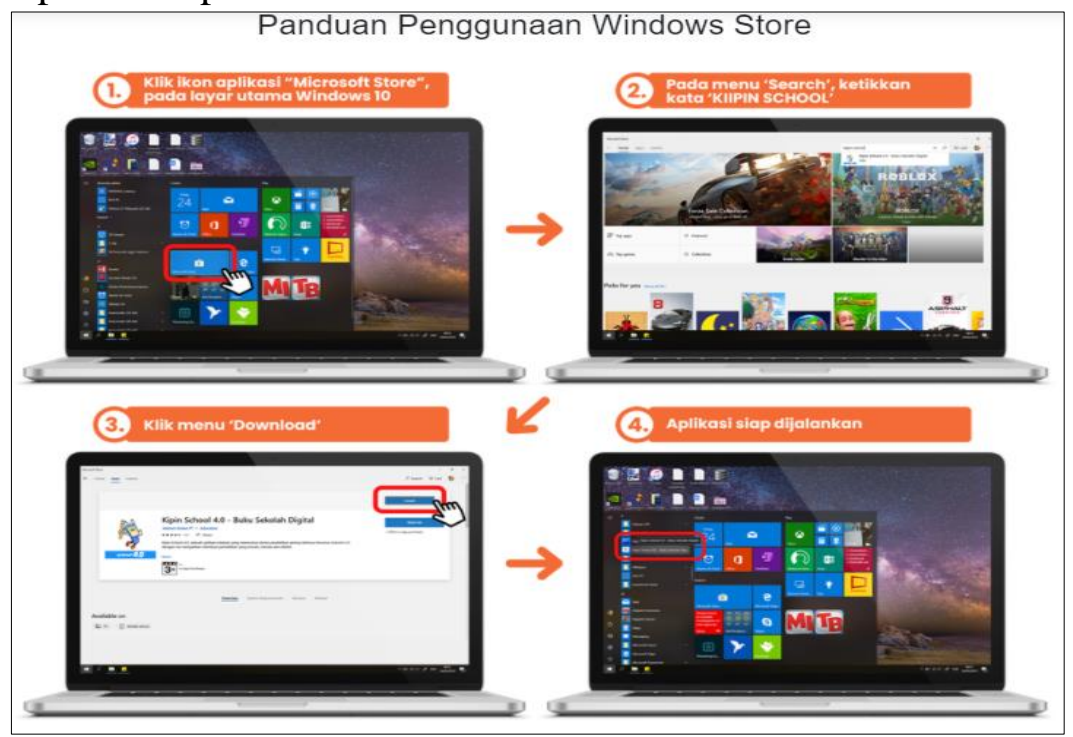


Setelah aplikasi terinstal, buat akun dengan cara klik daftar sekarang.

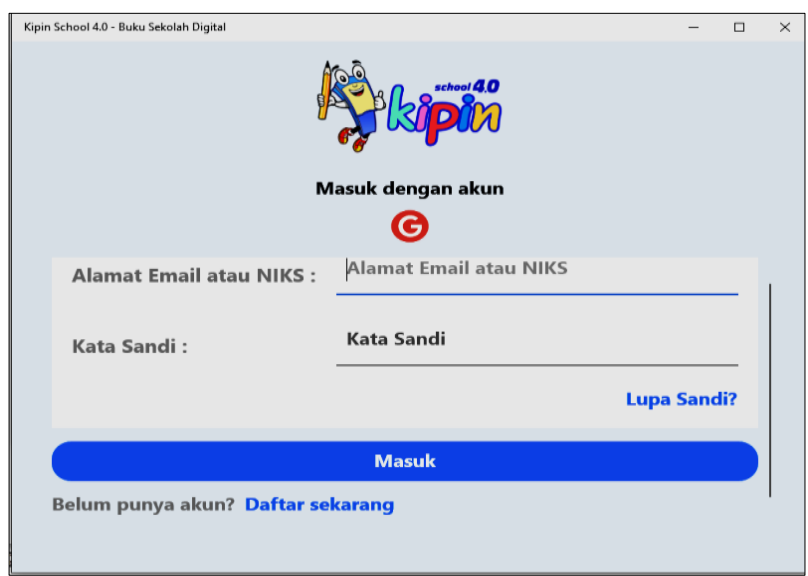

Setelah klik daftar sekarang, lalu isikan email, sandi, jenis kelamin dan klik daftar.

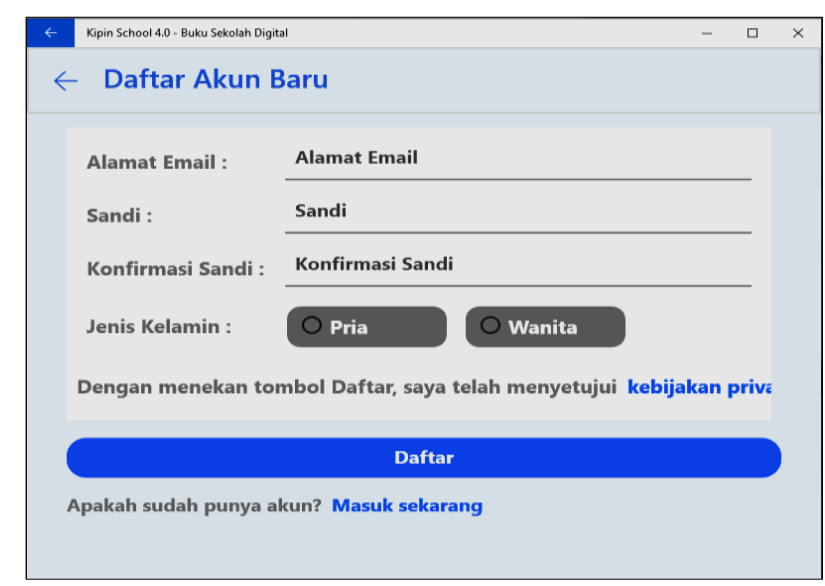

Setelah memiliki akun lalu login dan akan muncul tampilan seperti gambar, klik menu sekolahku untuk memulai membuat asesmen.

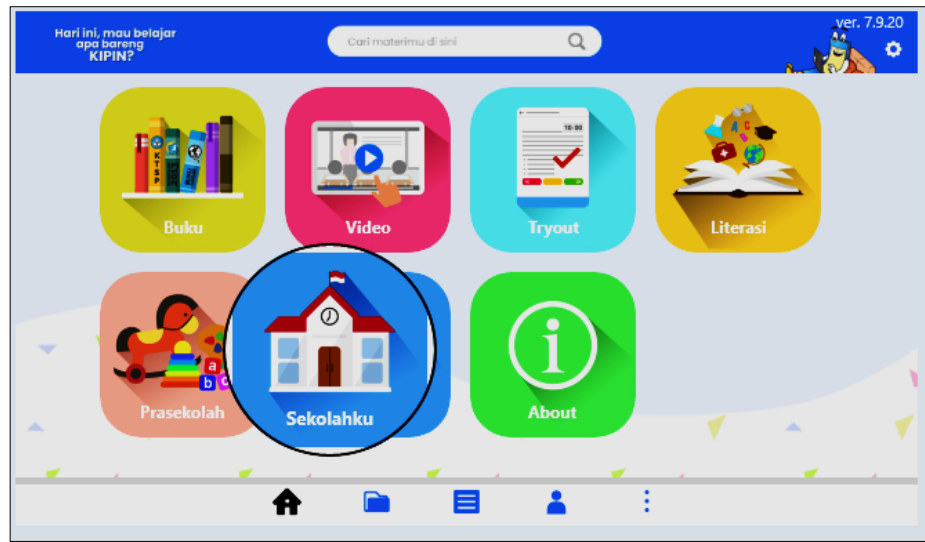

Pada menu sekolahku pilih Paperless Test Offline (PTO). 
Tampilan beranda PTO.
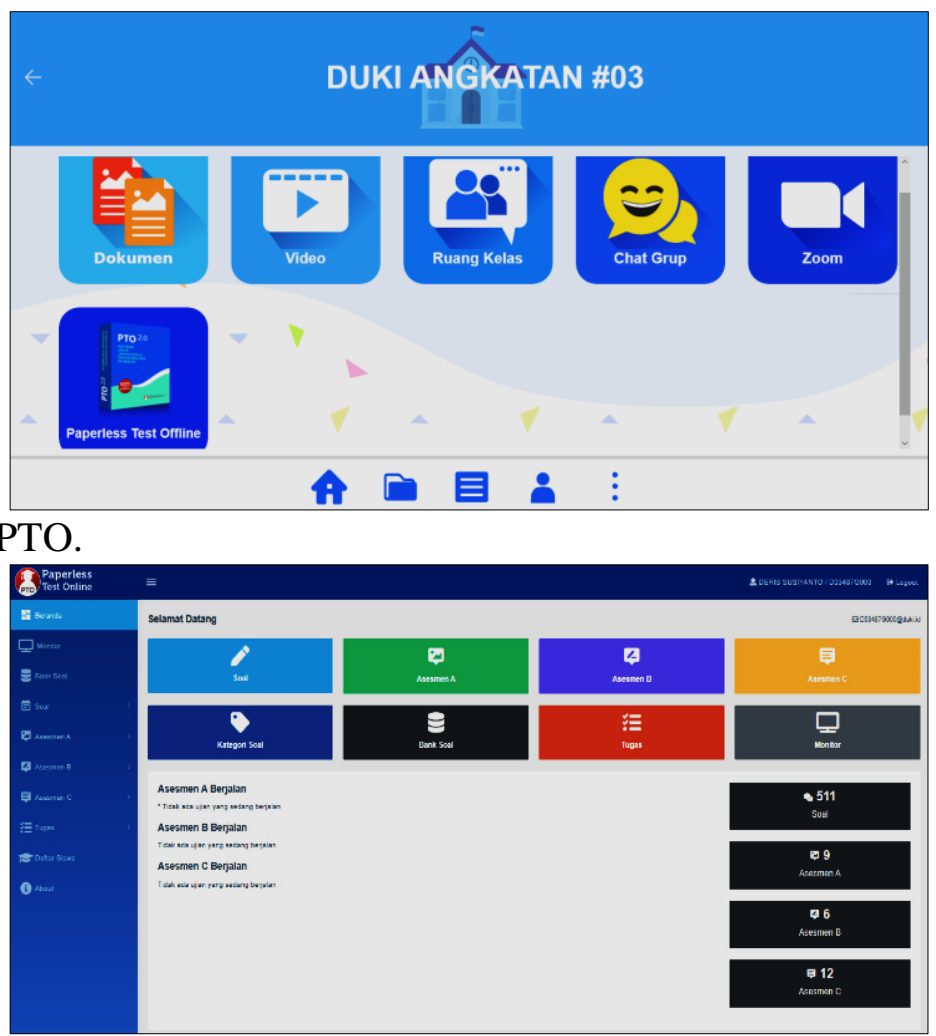

\section{Pandua siswa mengerjakan tes}

Lakukan login pada PTO menggunakan NIKS dan password

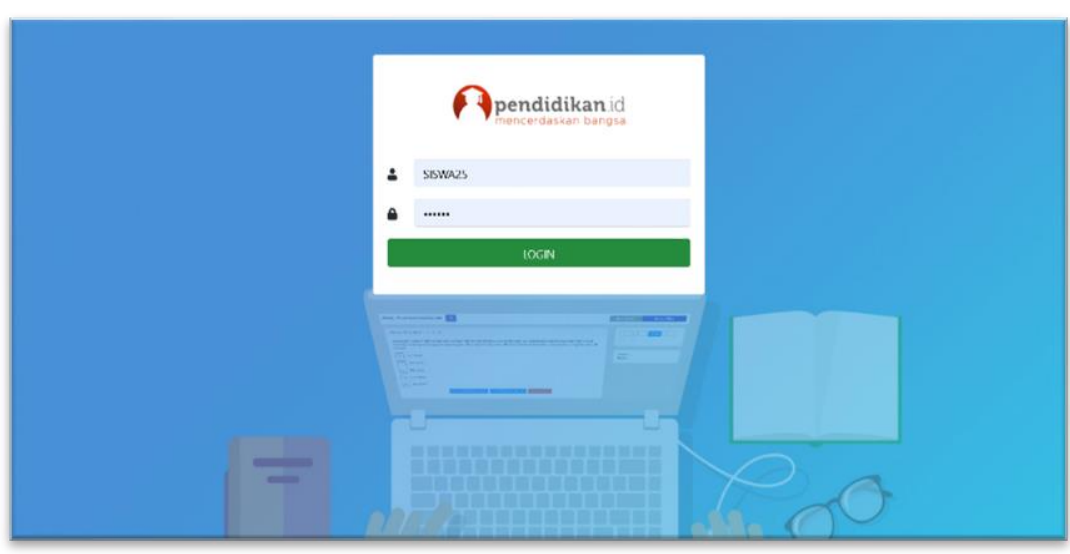

Untuk mengakses Asesmen A, pada beranda pilih Asesmen A. Atau klik Asesmen A pada kolom sebelah kiri.

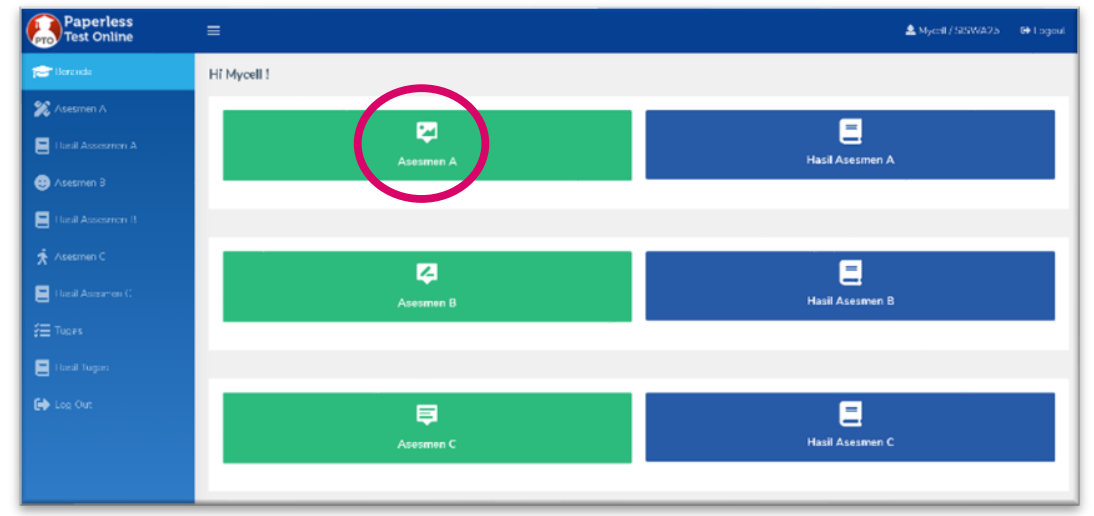

Pilih folder guru terkait yang akan dikerjakan Asesmennya. 


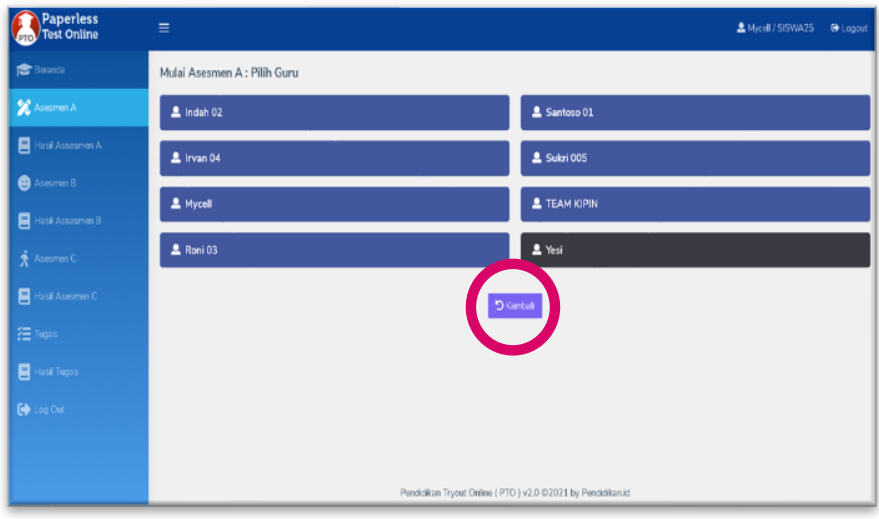

Pilih Asesmen yang dibuat oleh guru terkait dengan klik Mulai/Resume

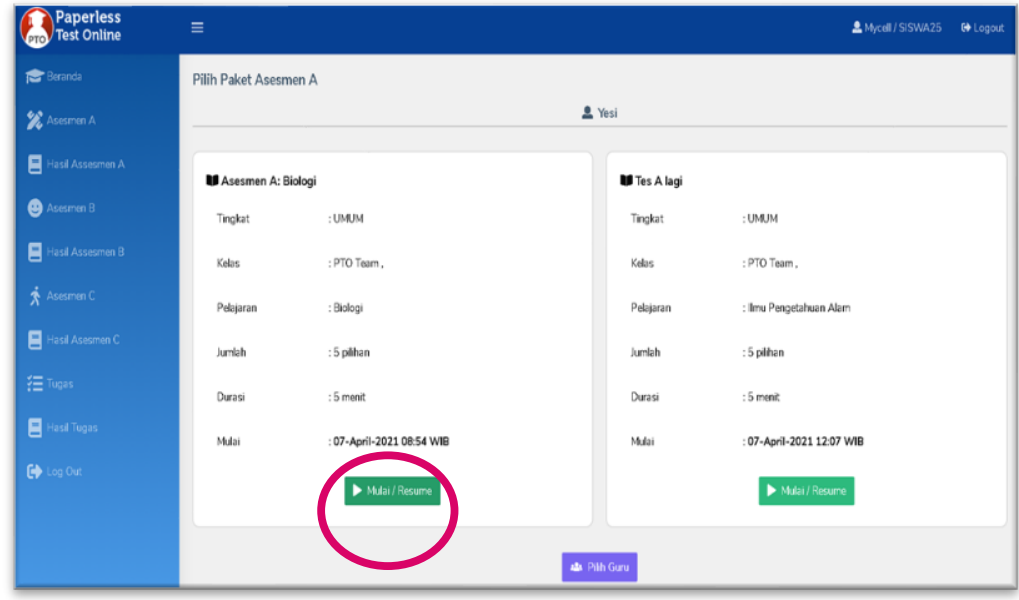

Klik Mulai setelah memahami keterangan tryout yang akan dikerjakan

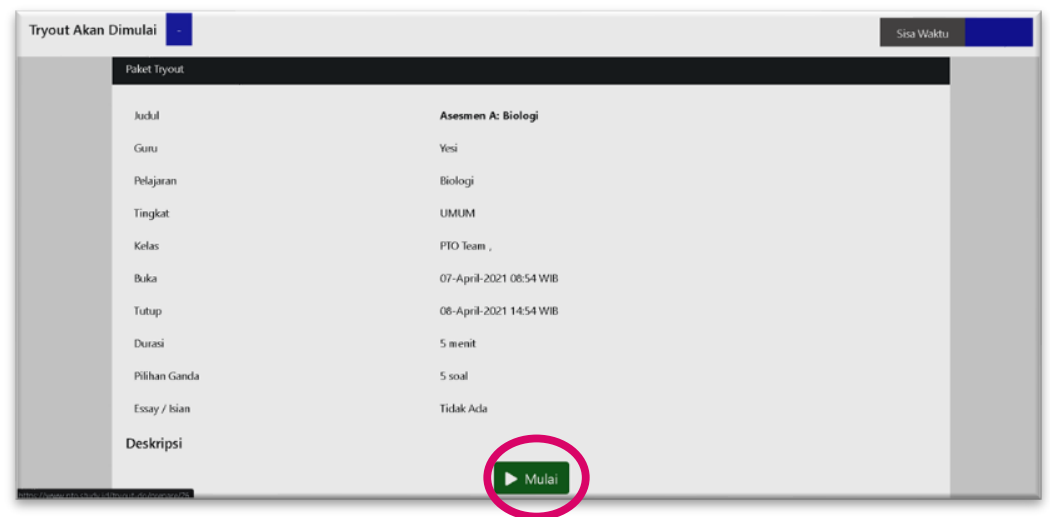

Tampilan saat mengerjakan soal

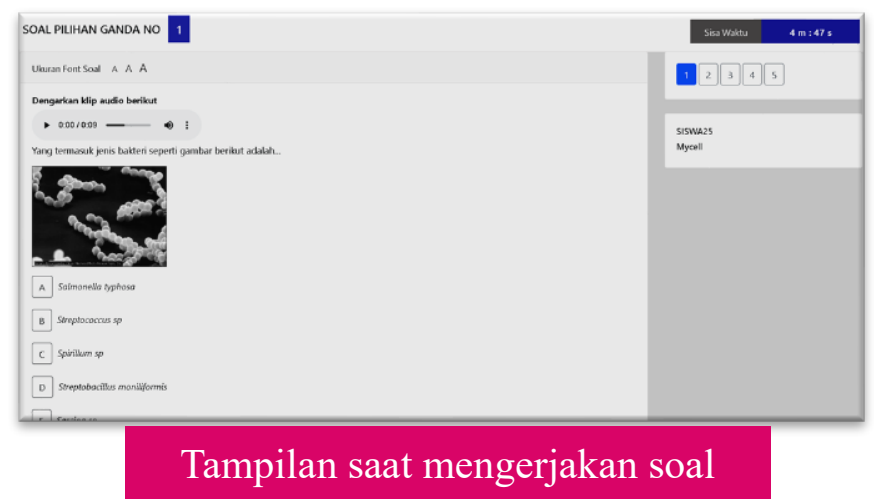


Saat telah selesai mengerjakan dan tiba pada nomor terakhir, klik selesai

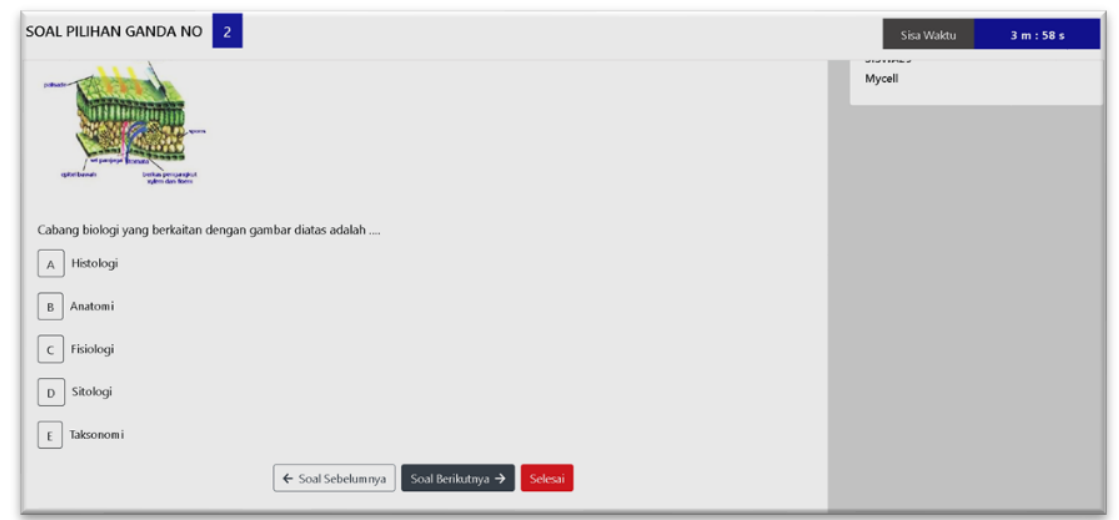

Siswa dapat mengecek kembali tryout yang telah telah dikerjakan dengan klik Periksa Jawaban. Dan dapat menyelesaikan tryout dengan klik Selesai/kumpulkan

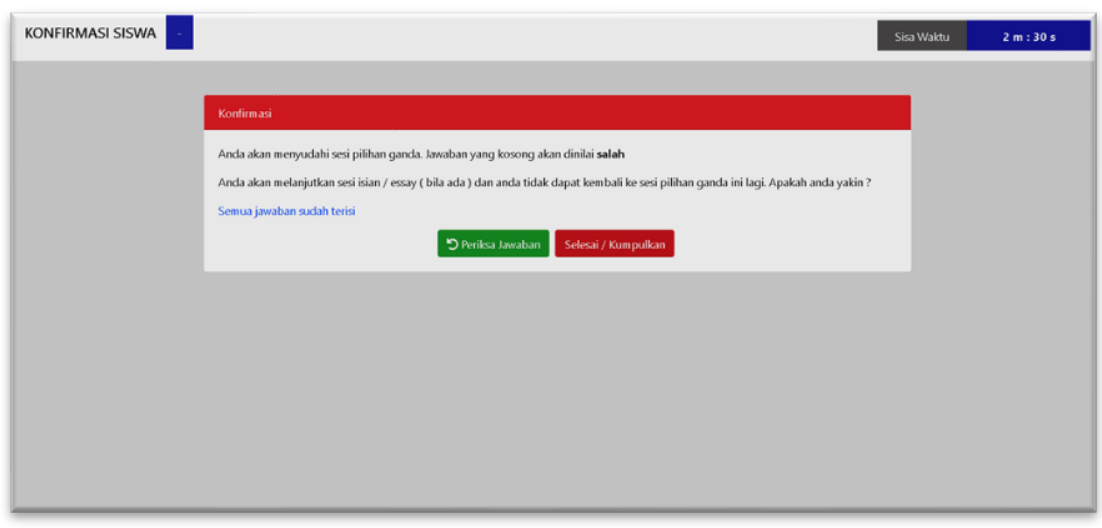

Tryout/Asesmen A telah berhasil dikerjakan dan dikumpulkan, maka akan muncul halaman seperti diatas. Klik OK

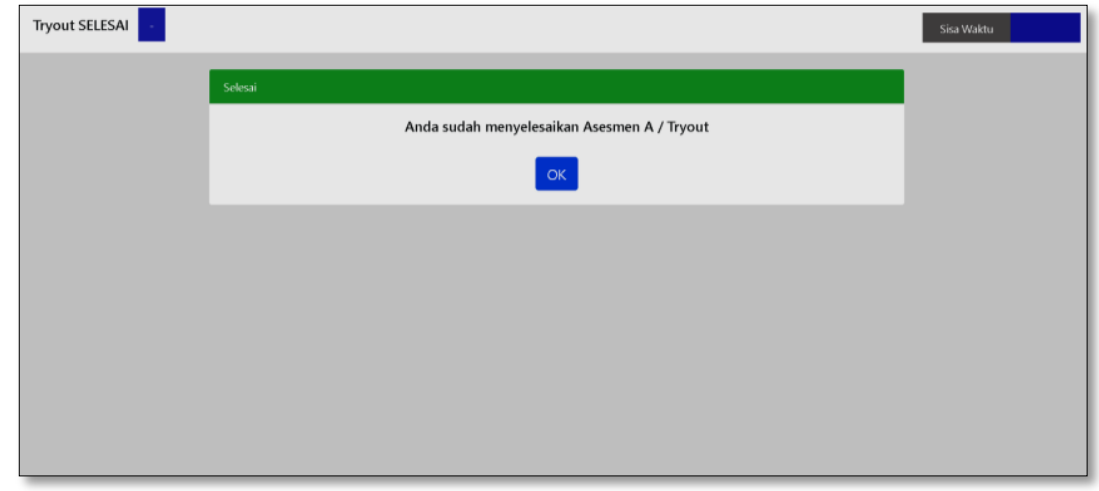

\section{B. Pemanfaatan Kipin PTO Sebagai Media Asesmen Digital Pembelajaran Daring}

Kipin PTO merupakan program "Sekolah menuju 100\% digital", yaitu dengan digitalisasi pelaksanaan asesmen dan ujian di sekolah menggantikan pemakaian kertas yang selama ini dipakai menjadi berbasis digital. Kipin PTO dapat dimanfaatkan semaksimal mungkin tanpa biaya tambahan lagi. Diantara keunggulan Kipin PTO 2.0 adalah sebagai berikut.

a. Mengerjakan soal dengan menggunakan smartphone, tablet atau PC yang sudah tersedia.

b. Input soal oleh (guru) sangat mudah dengan menggunakan Ms Word/Excel, selesai dalam hitungan menit

c. Mendukung berbagai macam jenis soal: multiple choice, essay, dengan bobot ditentukan oleh guru, kerja tugas, dll 
d. Sistem acak, nomor urut soal masing-masing siswa berbeda yang bertujuan untuk menghindari kecurangan/mencontek oleh siswa

e. Guru dengan mudah mengatur kapan asesmen dimulai dan diakhiri secara otomatis.

f. Private room: data antar guru terpisah dari guru lain, tidak dapat saling mencampuri.

g. Tampilan standar nasional, mudah dipahami oleh siswa dan guru

h. Tersedia peta jawaban hasil ujian siswa sebagai bahan analisis tingkat kesulitan pertanyaan

Menurut (Fadlilah et al., 2021) assessment atau penilaian adalah proses yang dilakukan oleh pendidik kepada peserta didiknya untuk mengetahui kemajuan belajar peserta didik dalam proses pembelajaran. Asesmen sangatlah berbeda dengan tes dan evaluasi. tes merupakan alat untuk mengetahui kemajuan belajar mengajar dengan menghasilkan nilai atau skor. Sedangkan, evaluasi menurut (Hardianti, Taufiq, \& Pamelasari, 2017) merupakan suatu proses sistematis yang berkelanjutan berdasarkan kriteria yang telah ditentukan. Selain itu, tujuan dari pelaksanaan evaluasi yaitu guna mendapatkan informasi yang objektif terhadap program tertentu yang telah ditentukan (Widyoko, 2016) Sedangkan asesmen tidak hanya tentang skor atau nilai tetapi lebih berupa feedback dan komentar lainnya yang dapat memberikan perubahan lebih baik kepada peserta didik di dalam proses pembelajaraan. Asesmen lebih mengutamakan proses belajar peserta didik dari pada hasil akhir atau nilai yang di dapat oleh peserta didik (Ahmad, 2020). Penilaian atau asesmen merupakan salah satu kegiatan yang menafsirkan data dari hasil pengukuran kompetensi peserta didik setelah mengikuti proses pembelajaran (Firdaus, Salsabila, \& Mahdalina, 2021).

\section{Tingkat kepuasan siswa saat menggunakan Kipin PTO dalam asesmen digital.}

Sebanyak 23 responden yang telah menggunakan Kipin PTO. Daftar pertanyaan tingkat kepuasan Kipin PTO yang digunakan pada penelitian ini menggunakan indikator respon peserta didik sebanyak 14 butir pernyataan.

Tabel 2 Rekapitulasi Responden

\begin{tabular}{|c|c|c|c|c|c|c|c|}
\hline Nomor & $\begin{array}{c}\text { Indikator } \\
\text { Respon } \\
(I d)\end{array}$ & $\begin{array}{c}\text { Sangat } \\
\text { setuju }\end{array}$ & Setuju & $\begin{array}{c}\text { Cukup } \\
\text { setuju }\end{array}$ & $\begin{array}{c}\text { Tidak } \\
\text { setuju }\end{array}$ & $\begin{array}{c}\text { Sangat } \\
\text { tidak } \\
\text { setuju }\end{array}$ & $\begin{array}{c}\text { Jumlah } \\
\text { Responden }\end{array}$ \\
\hline 1 & $I d_{1}$ & 3 & 19 & 1 & 0 & 0 & 23 \\
\hline 2 & $I d_{2}$ & 3 & 16 & 4 & 0 & 0 & 23 \\
\hline 3 & $I d_{3}$ & 3 & 16 & 2 & 2 & 0 & 23 \\
\hline 4 & $I d_{4}$ & 5 & 16 & 1 & 1 & 0 & 23 \\
\hline 5 & $I d_{5}$ & 7 & 16 & 0 & 0 & 0 & 23 \\
\hline 6 & $I d_{6}$ & 5 & 18 & 0 & 0 & 0 & 23 \\
\hline 7 & $I d_{7}$ & 4 & 17 & 2 & 0 & 0 & 23 \\
\hline 8 & $I d_{8}$ & 4 & 14 & 2 & 3 & 0 & 23 \\
\hline 9 & $I d_{9}$ & 2 & 18 & 3 & 0 & 0 & 23 \\
\hline 10 & $I d_{10}$ & 4 & 18 & 1 & 0 & 0 & 23 \\
\hline 11 & $I d_{11}$ & 3 & 19 & 1 & 0 & 0 & 23 \\
\hline 12 & $I d_{12}$ & 5 & 18 & 0 & 0 & 0 & 23 \\
\hline 13 & $I d_{13}$ & 3 & 18 & 1 & 1 & 0 & 23 \\
\hline 14 & $I d_{14}$ & 4 & 18 & 1 & 0 & 0 & 23 \\
\hline
\end{tabular}

Berdasarkan hasil survei responden peserta didik terhadap pemanfaatan Kipin PTO dalam pelakasanaan asesmen dapat dilihat pada tabel 2 di atas. Jika melihat dari data tersebut bahwa tingkat kebermanfaatan dalam penggunaan aplikasi Kipin PTO di atas 60\%, ini diperoleh dari respon setuju terendah yakni pada indikator respon (Id) ke- 8 (Id 8 ) = $14 / 23 \times 100 \%=60,86 \%$. 
Vol 1. No. 4, Oktober 2021 P-ISSN : 2774-8030, e-ISSN : 2774-8030

Tabel 3 Kriteria Tingkat Kepuasan

\begin{tabular}{cc}
\hline Skala & Tingkat Kepuasan \\
\hline $0 \%-20 \%$ & Sangat tidak setuju \\
\hline $21 \%-40 \%$ & Tidak setuju \\
\hline $41 \%-60 \%$ & Cukup setuju \\
\hline $61 \%-80 \%$ & Setuju \\
\hline $81 \%-100 \%$ & Sangat setuju \\
\hline
\end{tabular}

\section{KESIMPULAN}

Dengan perkembangan teknologi maka banyak aplikasi pembelajaran online berbasis android yang dapat digunakan dan diunduh oleh guru untuk melaksanakan pembelajaran. Salah satu media asesmen digital dalam pembelajaran yang dapat dimanfaatkan adalah Kipin PTO, yang dapat memberikan manfaat dalam pembelajaran, karena media ini menarik dan dapat memotivasi secara kerja otak dan olah manajemen waktu.

Pemanfaatan aplikasi Kipin PTO diharapkan dapat menjadi alternatif dalam menyelesaikan masalah asesmen digital dalam pembelajaran saat pandemic yang menunjang pembelajaran jarak jauh, karena media ini mengutamakan kreativitas, manajemen waktu, evaluasi siswa sampai pelaporan hasil asesemen.

\section{DAFTAR PUSTAKA}

Abidin, Y. (2014). Desain Sistem Pembelajaran dalam Konteks Kurikulum 2013. Bandung: PT Refika Aditama.

Ahmad, I. F. (2020). Asesmen Alternatif Dalam Pembelajaran Jarak Jauh Pada Masa Darurat Penyebaran Coronavirus Disease (Covid-19) Di Indonesia. PEDAGOGIK: Jurnal Pendidikan, 7(1), 195-222. https://doi.org/10.33650/pjp.v7i1.1136

Djuniarty, Eka. (2021). Wawancara langsung terkait "Media Pembelajaran berbasis Aplikasi" SD Negeri 012 Buluh Rampai, Riau.

Firdaus, Salsabila, \& Mahdalina. (2021). Dampak Covid-19 Terhadap Kebijakan Pendidikan di Indonesia: antara Idealisme dan Realitas. Yogyakarta: UAD PRESS

Hardianti, Taufiq, \& Pamelasari. (2017). The Development of Alternatif Assesment Instrument in Web Based Scientific Communication Skill in Science Education.

Irwan, I., Luthfi, Z. F., \& Waldi. (2019). Efektifitas Penggunaan Kahoot! untuk Meningkatkan Hasil Belajar Siswa [Effectiveness of Using Kahoot! to Improve Student Learning Outcomes]. Pedagogia : Jurnal Pendidikan, 1(8)

Kasali, Rhenald. (2019). "Disruption”. Jakarta: PT Gramedia Pustaka Utama, cet. Ke-10.

Pakpahan, R., \& Fitriani, Y. (2020). Analisa Pemafaatan Teknologi Informasi Dalam Pemeblajaran Jarak Jauh Di Tengah Pandemi Virus Corona Covid-19. JISAMAR (Journal of Information System, Applied, Management, Accounting and Researh), 4(2), 30-36.

Paul Gilster. (1997). “Digital Literacy”. New York : Wiley Computer Pub., c1997.

S. Eko Putro Widoyoko. (2016). Evaluasi Program Pembelajaran, Panduan Praktis Bagi Pendidik dan Calon Pendidik. Yogyakarta: Pustaka Pelajar

Sari, W., Rifki, A. M., \& Karmila, M. (2020). Pembelajaran Jarak Jauh Pada Masa Darurat Covid 19. Jurnal MAPPESONA, (1), 12.

Shoimin, A,. (2014). Model Pembelajaran Inovatif dalam Kurikulum 2013. Yogjakarta : ARRuzz Media.

Supriyadi, G. (2011). Pengantar \& Teknik Evaluasi Pembelajaran. Malang: Intimedia. 